\title{
Establishment of the inventory of the historic bridges analyzing the maps of Europe in the XIX. Century, in the area of Split-Dalmatia County, Croatia
}

\author{
Katarina Rogulj a,*, Ivana Racetin ${ }^{\text {a }}$, Jelena Kilić a , Ljerka Županović b \\ ${ }^{a}$ Faculty of Civil Engineering, Architecture and Geodesy, Split, Croatia, University of Split, Matice hrvatske 15, 21000 Split, \\ Croatia; katarina.rogulj@gradst.hr; ivana.racetin@gradst.hr;jelena.kilic@gradst.hr \\ ${ }^{b}$ Hydrographic Institute of the Republic of Croatia, Zrinsko-Frankopanska 161, 21000 Split, Croatia; ljzupanovic@gmail.com \\ * Corresponding author: katarina.rogulj@gradst.hr
}

\begin{abstract}
Croatia is a country rich with monuments, enchanting historic buildings, and rife cultural heritage. The paper presents main aspects of the research on the identifying the historic bridges built till the end of the Austro Hungarian monarchy (AHM) (till 1918), and by their identification, the inventory of these bridges was established. The Croatian territory, specifically, Dalmatia is brimming with rivers, lakes, streams, etc., so the bridge construction was indeed necessary and often in usage in this area. There are various reasons why all these bridges are not preserved until today. Because of this, authors found it important to define the total number of these bridges that will need further qualitative and sustainable preservation, remediation and management. The research started by collecting the data from various institutions and interviewing conservatives, historians, managers of these bridges and also the local habitants. When the data were collected, European maps from the XIX. Century were analyzed with the intention to find which of the identified bridges belong to the period of the AHM. Bridges found on those maps were later compared with modern maps to define how many of them still exist. The aim is to establish the inventory of the historic bridges built till the end of the AHM in the area of Split-Dalmatian County.
\end{abstract}

Keywords: inventory establishment, historic bridges, map analysis, maps of Europe in XIX. Century

\section{Introduction}

The Austro Hungarian monarchs produced detailed maps of its provinces and borders for the first time in the second half of the eighteenth century by military engineers (Veres, 2015). Monarchs, during their period of the ruling, among other contributions, built a lot of famous buildings and monuments for the wellbeing of the Monarchy and its citizens.

Since the territory of Split-Dalmatian County, Croatia was a part of the monarchy the same was done in that area. As that territory is rich with rivers, lakes, streams, etc., bridge engineering was very needed and used profession. Most of the bridges were built over rivers Cetina, Jadro, Vrlika, Žrnovnica, etc. During the World Wars, some of the bridges were destroyed, and some were flooded later in the construction of the hydropower plant. Some were demolished due to the new road construction, so there is no exact number of the historic bridges. For this reason, the authors found it very important to establish a list of bridges built till the end of the Austro Hungarian monarchy (as one of the most important Croatian historical event) and which survived till today. It was necessary to identify their locations. In the beginning, it was important to collect data from various institutions. In the State Archive in Zadar, Croatia, documentation like drafts, calculations, licenses, etc. were collected. This documentation provided data like the number of bridges, their characteristics (materials, length, width, number and size of spans, etc.), locations, short descriptions, bridge disadvantages, etc. The number of around 90 bridges (which from the conversation with conservative experts in Split-Dalmatian County was not final) was found. Also, data were collected in the Departments of Conservatory in Split and Imotski, were an approximate number of bridges that are still in traffic function was obtained. Multiple interviews and unformed conversations were made with scientists, conservators, civil engineers and architects, managers of county roads that manage historic bridges, historians and local habitants. It was meant to find out how many of these bridges are still out there and how many of them are in everyday use.

From the all above mentioned, the authors concluded that this number is still unknown and due to that, it was necessary to found the appropriate methodology that will assist in numbering and locating of the historic bridges. Analyzing old maps from the XIX. Century of Europe assisted in establishing the total number of these bridges. Using those maps the number and locations of historic bridges were established. After that, field research was made to identify all these bridges and to estimate their current state. Only 36 bridges were found, and most of them are concentrated around the area of towns: Imotski, 
Vrgorac, Trilj, Solin, Kaštela, and Trogir. Those bridges have medium to low functionality because of their condition that barely tolerates today's traffic capacity. They are managed by the Department of county roads of Split-Dalmatian County, the Roads of Croatia, and by the Ministry of Culture. All of the identified bridges are listed, and the list can be used further in various research and practical activities.

The research aimed to establish the inventory of the historic bridges in Split-Dalmatian County built during the Austro Hungarian monarchy period, using maps of Europe in XIX. Century. Mapping and identifying these bridges can enable, road and bridge managers, civil engineers and architects, conservatives and experts dealing with historical buildings, to get systematic and practical approach in managing, maintaining, remediating, replacing and removing (if necessary) of the mentioned bridges. By establishing the inventory of the historic bridges a sustainable model, for managing of heritage buildings can be further obtained. That can make the decision-making process in carrying out various engineering, architectural and conservation activities on these bridges more precise, accessible and practical.

\section{Materials}

The identification of bridges was provided using different maps of Europe in XIX. Century. Some of those maps are maps of Dalmatian territory produced between the years 1851 and 1854. They were one of the results of a Second Topographic Survey of the Habsburg Empire. The first military mapping was the first systematic military geodetic survey done on the territory of the former Austro Hungarian monarchy. Most of these military surveys were done during the reign of the Empress Maria-Theresia and the complete mapping was finished by the reign of her son Emperor Joseph I. Insufficient quality of maps from the first military mapping led to the beginning of the new surveys in the XIX. Century, under the reign of the emperor Franz II. The second military mapping was done during 1819-1858 on the territory of the current Czech Republic while the mapping works on the territory of the whole monarchy took much more (1807-1869). The mapping had been preceded by the creation of a trigonometric network used also for the cadastral survey as a background for a topographic survey (Zimova, Pestak and Veverka, 2006).

The whole Second Topographic Survey of the Habsburg Empire, lasted around sixty years and was completed in the 1860s. It was a period of time with a huge surveying development. The Second (also known as Franciscan) Topographic Survey (Jankó, 2001) is a masterpiece of the map series representing the territory of the Austro Hungarian Empire. It is outstanding in quality regarding its data content, drawing features and aesthetic appearance. Although the series is not uniform in its content and in its implementation due to the extended period of time of the mapping (1806-1869), according to recent experience in its present-day usage, its map sheets are fairly well applicable even today (Timár et al, 2006).
Figure 1. shows the map of Europe during the ruling period of Austro Hungarian monarchy in XIX. Century.

The content of many sheets of the Second Topographic Survey maps was several decades old. It was the main reason why a new survey in the Empire, today called the Third Topographic Survey was carried out. Map series of a scale of 1:25 000 and 1:75000 were made within the framework of the third survey (Molnár and Timár, 2009).

Map created by Giustino Antonio Grandis in the year 1781 was also used in the research (Figure 2). The content of the map is Dalmatian territory, specifically, the town of Imotski and its surrounding (Ćosić et al, 2012). It is probably one of the best pre-modern maps of Dalmatia, especially its illustrations of the continental part. On that handmade map the newly discovered geographic knowledge about Dalmatia, collected after delimitation and through a cadastral survey, was merged with the best cartographic visualization, displaying the topographic features of the terrain. According to the scale in the Italian miles, the map was made at an approximate scale of 1 : 98000. It shows detailed state and internal borders, toponyms, hydrographic elements, and soil types. The particularity of Grandis's map is also an unusual orientation of the sheet relative to the world's (north-south) regions. The data are shown in a way that they have to be read from the land side and not for that area usual seaside.

Authors also analyzed some other maps. One of them is a map of Dalmatia made by Francesco Melchiori, Lodovico Furlanetto and Frane Zavoreo published in Venice in the year 1787 (Magaš et al, 1997; Slukan Altić, 2003; Ćosić, 2007: from Ćosić et al, 2012). That map, from the Venetian period of governing Dalmatia County, was analyzed to locate the bridges built before the Austro Hungarian monarchs.

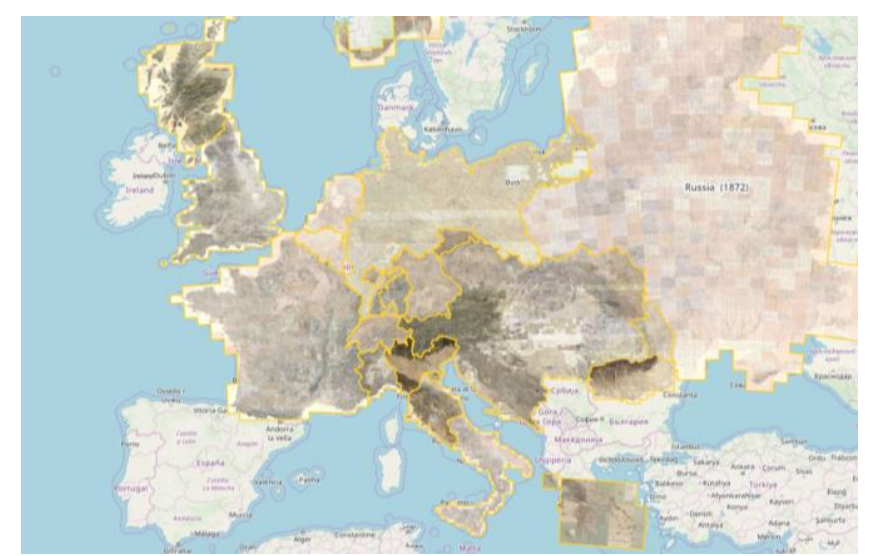

Figure 1. The map of Europe during the period of the Austro Hungarian monarchy in XIX. Century (Europe in the XIX. Century (with the Topographic Survey 1:75000) (Mapire-The Historical Map Portal). 


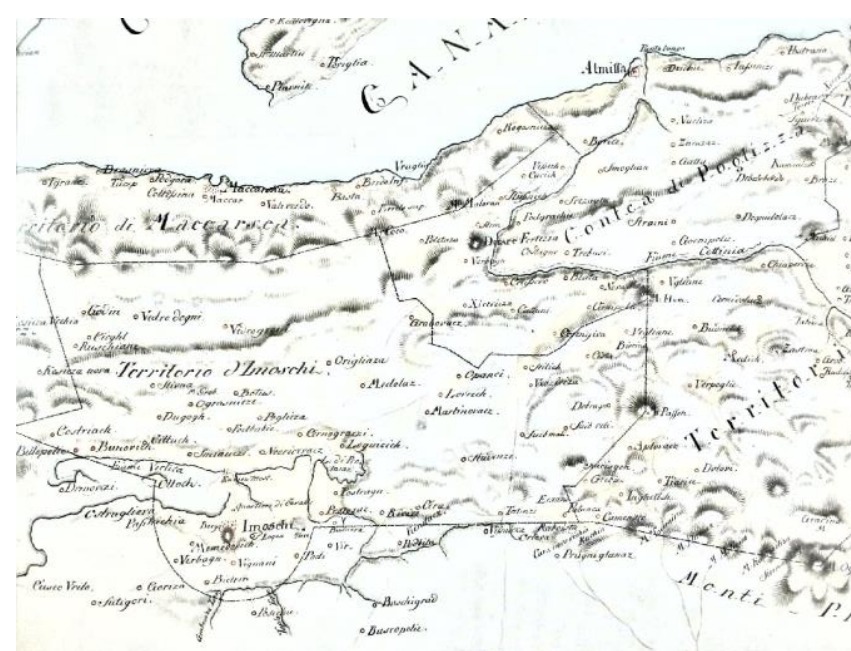

Figure 2. Dalmatia (Imotski and its surroundings), 1781, 1:98000, Guistino Antonio Grandis, Geographic and topographic maps, no. 321 (Ćosić et al, 2012).

\section{Maps analysis}

The analysis of the maps started with the division of SplitDalmatia County on three areas defined as:

1) Split-Makarska-Islands

2) Vrlika-Sinj

3) Imtoski-Vrgorac

After that, each area was detailed analyzed and the bridges were localized. Figure 3. shows the extrusion of SplitDalmatian County and its division on areas. Green colored is the area of the Split-Makarska-Islands, yellow is the Vrlika-Sinj area, and Imotski-Vrgorac area is orange.

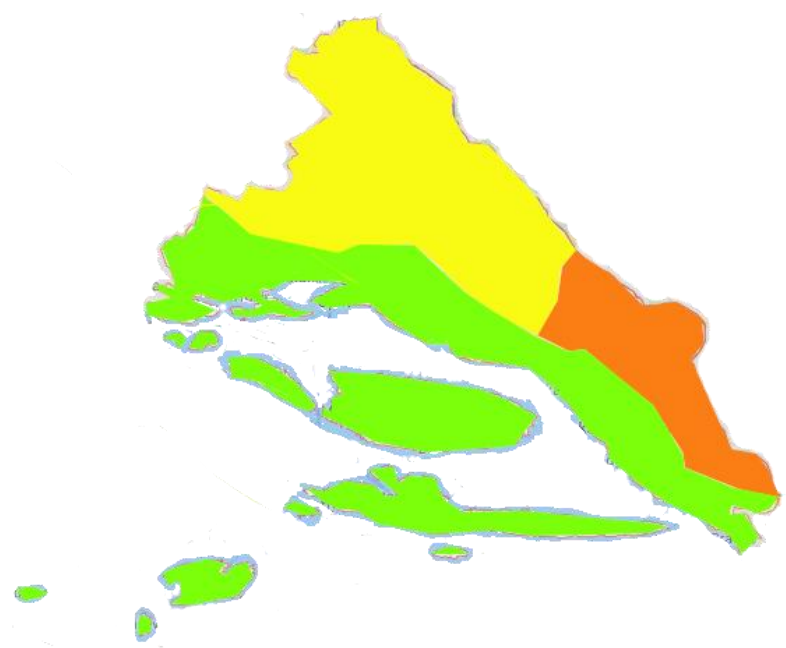

Figure 3. Split-Dalmatian County divided in three areas.

Division on the areas led to the cumulating of the bridges built till the end of the Austro Hungarian monarchy. Authors also included the bridges from the documentation collected from the Archive in Zadar. In Table 1, the total number of bridges for each area of the Split-Dalmatian County is given.

\begin{tabular}{|l|c|}
\hline Area & Total number \\
\hline Split-Makarska-Islands & 69 \\
\hline Vrlika-Sinj & 29 \\
\hline Imtoski-Vrgorac & 13 \\
\hline
\end{tabular}

Table 1. The number of historic bridges given for each area of Split-Dalmatian County.

As it can be seen from Table 1, the area of SplitMakarska-Islands had the highest number of bridges, 69, while the lowest had the area of Imtoski-Vrgorac. The total number of bridges was 111 . It must be taken into account that the analyzed maps are dating from the late 80s of the XIX. Century. For this reason, it is unknown how many bridges were built from that period to 1918 . Due to this, as it is mentioned before, authors used the documents form Archive that also helped in the definition of the total number of bridges.

After the definition of the number of historic bridges built till the end of the Austro Hungarian monarchy, the next step was to define the list of these bridges survived till today. Using ArcGIS, authors localized and marked the bridges. Today, some of these bridges are pedestrian and some of them are road bridges. On Figure 4, a spatial distribution of the historic bridges is given. Blue marked are road bridges, while red marked are pedestrian.

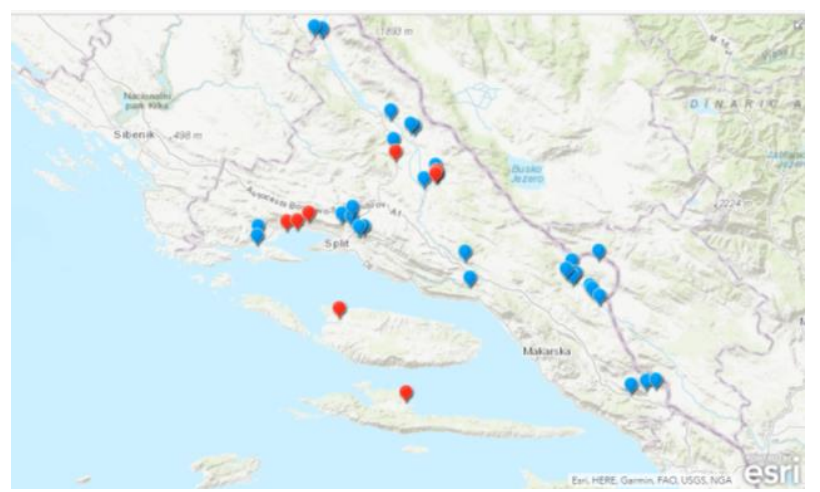

Figure 4. Spatial distribution of historic bridges in SplitDalmatia County (blue marked are road bridges, red marked are pedestrian bridges).

Localizing the bridges on the maps, a total of 36 historic bridges were identified. Tables 2 and 3 show the list of the road and pedestrian bridges, respectively. Both lists are divided into the areas, provided that the list of pedestrian bridges has not the area of Imotski-Vrgorac because no bridges were identified in that area.

For the historic road bridges, 27 bridges are identified, among which nine are in the area of Split-Dalmatia County, seven in the area of Vrlika-Sinj, while eleven are in the area of Imotski-Vrgorac.

As for the pedestrian bridges, only nine were localized, five in the area of Split-Makarska-Islands and four in the area of Vrlika-Sinj. 


\begin{tabular}{|l|l|}
\hline \multicolumn{2}{|c|}{ Split-Makarska-Islands } \\
\hline Name & Location \\
\hline Bridge by the stonepit “Lavčević" & Žrnovnica \\
\hline Žrnovnica Bridge & Žrnovnica \\
\hline Bridge over river Jadro & Solin \\
\hline Bridge by factory “Majdan” & Solin \\
\hline Rera Bridge & Klis \\
\hline Blato na Cetini Bridge & Blato na Cetini \\
\hline Pavića Bridge & Podgrađe \\
\hline Small Bridge & Trogir \\
\hline Čiovo Bridge & Trogir \\
\hline \multicolumn{2}{|l|}{} \\
\hline Grab Bridge & Grab \\
\hline Kosinac Bridge & Gala \\
\hline Panj Bridge & Rumin \\
\hline Balečki Bridge & Vinalić \\
\hline Han Bridge & Obrovac Sinjski \\
\hline Kosore Bridge & Kosore \\
\hline Lubin Bridge & Sinj \\
\hline \multicolumn{2}{|l|}{} \\
\hline Jovića Bridge & Vinjani Gornji \\
\hline Bridge over river Matica & Kokorići \\
\hline Bridge in Rastoke & Vrgorac \\
\hline Brvina Bridge & Runović \\
\hline Bublin Bridge & Zmijavci \\
\hline Zmijavci Bridge & Zmijavci \\
\hline Bridge over stream Suvaja & Donji Proložac \\
\hline Šumet Bridge & Šumet \\
\hline Jasenovac Bridge & Jasenovsko \\
\hline Bridge over stream Jaruga & Grubine \\
\hline Kamenmost Bridge & Kamnemost \\
\hline Tab & \\
\hline
\end{tabular}

Table 2. The list of historic road bridges of each area.

\begin{tabular}{|l|l|}
\hline \multicolumn{2}{|c|}{ Split-Makarska-Islands } \\
\hline Name & Location \\
\hline Kaštilac Bridge & Kaštel Gomilica \\
\hline Ričevica Bridge & Kaštel Stari \\
\hline Castel Vitturi Bridge & Kaštel Lukšić \\
\hline Vrboska Bridge & Hvar \\
\hline Franjo Josip Bridge & Ložišća, Brač \\
\hline \multicolumn{2}{|c|}{ Vrlika-Sinj } \\
\hline Bridge by Ćosić mill & Grab \\
\hline Bridge by Samarđić mill & Grab \\
\hline Small bridge over river Grab & Grab \\
\hline Goručica Bridge & Sinj \\
\hline
\end{tabular}

Table 3. The list of historic pedestrian bridges of each area.

\section{Conclusion}

The results of the maps analysis present the list of bridges built till the end of the period of the Austro Hungarian monarchy. Defining the list of these bridges, the inventory of historic road and pedestrian bridges is established. The maps of Europe from XIX. Century were used, but also the data collected from the Archive in Zadar helped to precise the inventory. Total of 111 bridges was identified and localized on the area of Split-Dalmatia County but only 36 of them survived till today. This result pointed out how turbulent were last 100 years, with lots of various historical and political, nature and human impact events that have had influence not just on these bridges, but on the overall cultural heritage. Preserving these 36 bridges is the crucial obligation for all involved, from managers to the end-user.

Maps of Europe in XIX. Century, covering whole territory of former Austro Hungarian monarchy, are irreplaceable information sources for the history and landscape development research and can be used by experts from different scientific and profession areas such as land management, archaeology, geographical sciences, environmental ecology, flood management and control, cartography, history, etc., and also for the bridge engineers and managers, conservators and architects. Establishing the inventory of the historic bridges can assist experts in the field of construction engineering and architecture, experts in conservation and preservation, and managers of these bridges in the various activates like remediation, replacement, monitoring, managing, etc. of bridges and enable them a development of systematic approach to the realization of the mentioned and necessary activities. The result of the research focused on defining the inventory of historic bridges, and among them, some are enrolled in cultural heritage but some are undeservedly neglected on that point. Establishing the inventory can contribute to the preservation of these bridges and improvement of their functionality and integration into the modern traffic demands.

\section{References}

Ćosić, S. (2007): Zagora na starim zemljopisnim kartama i katarstarskim planovima. U: Dalmatinska zagora, nepoznata zemlja. Galerija Klovićevi dvori I Ministarstvo kulutre, Zagreb, 205-219.

Ćosić, S., Alilović, M., Frangeš S., Landek, I. (2012): Topografske karte na području Hrvatske, Republika Hrvatska, Državna geodetska uprava, Zagreb.

Jankó, Annamária (2001): A második katonai felmérés. Hadtörténeti Közlemények 114: 103-129. (URL: http://epa.oszk.hu/00000/00018/00016/04janko.htm)

Magaš, D., Dokoza, S., Martinović, S. (1997): Hrvatska na zemljopisnim kartama od XVI. Do XIX. Stoljeća u Državnom arhivu u Zadru. Državni arhiv u Zadru, Zadar.

Mapire-The Historical Map Portal,

URL: https://mapire.eu/en/ (visited: January 02, 2019) 
Molnár, G., Timár, G. (2009): Mosaicking of the 1:75000 sheets of the Third Military Survey of the Habsburg Empire. Acta Geodaetica et Geophysica Hungarica 44(1): 115-120.

Slukan Altić, M. (2003): Povijesna kartografija. Kartografski izvori u povijesnim znanostima. Meridijan, Samobor.

Timár, G., Molnár, G., Székely, B., Biszak, S., Varga, J., Jankó, A. (2006): Digitized maps of the Habsburg Empire - The map sheets of the second military survey and their georeferenced version. Arcanum, Budapest, 59 p.

Veres, M. V. (2015): Constructing imperial spaces: habsburg cartography in the Age of enlightenment. Doctoral Dissertation, University of Pittsburgs, USA.

Zimova, R., Pestak, J., Veverka, B. (2006): Historical military mapping of the Czech lands - cartographic analysis. 